\title{
O DIREITO DA GUERRA EM FRANCISCO SUÁREZ: O PROJETO CIVILIZADOR DA ESCOLÁSTICA ESPANHOLA
}

\section{EL DERECHO DE LA GUERRA EN FRANCISCO SUÁRES: EL PROYECTO CIVILIZADOR DE LA ESPA- NA ESCOLÁSTICA}

\section{Paulo Emílio Vauthier Borges de Macedo ${ }^{1}$}

Resumo: O presente texto analisa o direito da guerra em Francisco Suárez. Menos uma explanação sobre um ramo do direito internacional, neste trabalho, busca investigar-se a origem deste direito, sob uma ótica bastante particular. Trata-se de reconstruir o intento de um dos maiores expositores da Escolástica Espanhola para salvar uma tradição cristã muito antiga da sua destruição. A doutrina da guerra justa, embora de origem cristã, corresponde a um dos maiores esforços da humanidade como um todo para limitar a violência da guerra, mesmo antes da existência de um direito internacional. Para manter a validade das proposições da teoria da guerra justa - e minimizar os efeitos da guerra -, Suárez precisou alterar-lhe o fundamento: de doutrina religiosa, ela se tornou jurídica.

Resumen: El presente texto analiza el derecho de guerra en Francisco Suárez. Más que una explicación sobre una rama del derecho internacional, este trabajo, busca investigar el origen de ese derecho desde una perspectiva muy particular. Trata de reconstruir el intento de uno de los mayores expositores de la Escolástica española de salvar una tradición cristiana muy antigua de su destrucción. La doctrina de la guerra justa, aunque de origen cristiano, corresponde a uno de los mayores esfuerzos de la humanidad en su conjunto para limitar la violencia de la guerra, incluso antes de la existencia de un derecho internacional. Para mantener la validez de las proposiciones de la teoría de la guerra justa - y minimizar los efectos de la guerra -, Suárez tuvo que cambiarle el fundamento: de doctrina religiosa, ella se convirtió en jurídica.

Palavras-chave: Francisco Suárez, Guerra Justa, Direito das Gentes

1 Professor Adjunto de Direito Internacional da Universidade do Estado do Rio de Janeiro, autor dos livros Guerra e Cooperação Internacional, Hugo Grócio e o Direito: o jurista da guerra e da paz e de O nascimento do direito internacional. E-mail: borgesmacedo@hotmail.com. Este trabalho é uma versão modificada de trechos da minha tese de doutorado. 
Palabras clave: Francisco Súarez, Guerra Justa, Derecho de Gentes

\section{Introdução}

Francisco Suárez, um dos maiores escritores da escolástica espanhola, nasceu em Granada, em 5 de janeiro de 1548 e morre em Lisboa, em 24 de setembro de 1617. Proclamado pela Igreja como Doctor Eximius et Pius, foi um dos fundadores do direito internacional. O internacionalista norte-americano James Brown Scott, numa feliz analogia, considera Francisco de Vitória o expositor inicial, Francisco Suárez o filósofo, e Hugo Grócio o sistematizador².

Todavia, consoante Pierre Mesnard - autor de uma importante obra sobre a história da filosofia política -, "nós [filósofos políticos] fomos, com frequência, injustos em relação a Suárez"3. O pensamento de Francisco Suárez influenciou sobremaneira a teologia católica e protestante, mas ele foi relegado entre os filósofos e os juristas. Sua maior obra jurídico-política, o De Legibus ac Deo Legislatore, acabou tão-somente por ganhar pó nas estantes das bibliotecas. Já o seu segundo maior texto neste gênero, a Defensio Fidei, foi, até mesmo, proibido em França e chegou a ser queimado na Inglaterra, tamanha a polêmica que causou. Isso deveria ser um indicativo das ideias que o escritor defende. Mesmo assim, por um bom tempo, os livros de Francisco Suárez não obtiveram acesso às academias de Direito e de Filosofia.

Somente na segunda metade do século XIX, quando se descobre que Hugo Grócio não detém, com exclusividade, a paternidade do direito internacional, os textos jurídicos e políticos de Suárez são revitalizados. Percebe-se, então, que Suárez não é apenas um grande teólogo - um dos maiores do chamado "século de ouro" da Espanha e o mais importante da segunda vaga da escolástica espanhola -, mas também antecipou teses jurídico-políticas bastante modernas como o contrato social, a origem popular do poder e a doutrina do tiranicídio. Além disso, o escritor apresenta uma noção de direito natural que se ajusta às mudanças históricas, o que salva o jusnaturalismo suareziano de uma das mais contundentes críticas que o positivismo desfere contra o direito natural moderno. Tão original é o pensamento do autor que ele desenvolveu uma concepção sofisticada e original de jus gentium que

2 Cf. SCOTT, J. B. The Catholic Conception of International Law. Washington D.C.: Georgetown University Press, 1934. pp. 183-184.

3 "On a souvent été injuste pour Suarez" (MESNARD, Pierre. L'Essor de la Philosophie Politique au XVIe Siècle. 3. ed. Paris: J. Vrin, 1977. p. 40). 
ultrapassou a órbita cultural romana na qual os trabalhos sobre o tema ainda estavam inseridos ${ }^{4}$.

Cabe observar que um internacionalista de hoje não conseguiria reconhecer o seu objeto de estudo nos textos de Suárez. Desavisado, ele encontraria apenas comentários à Suma Teológica de Santo Tomás de Aquino. Tampouco o seu direito internacional estaria em qualquer escritor do início do século XVII. Autores deste tempo ocuparam-se de temas bastante distintos daqueles que se leem nos sumários dos manuais contemporâneos. Eles se debruçaram sobre a doutrina da guerra justa, o direito de guerra medieval, da qual o jus gentium representa somente uma das suas fontes.

Suárez, no entanto, merece destaque precisamente por ser um comentarista bastante sistemático de Santo Tomás. O estudo da guerra no Aquinate encontra-se num tratado diferente daquele em que ele se volta para o Direito (e diferente também daquele em que ele se volta para as leis), no Tratado da Caridade. Assim, Suárez teve a oportunidade de se debruçar sobre o direito das gentes em dois momentos distintos da sua vida e sob dois ângulos bem diversos: quando redigiu o seus comentários sobre a caridade e, posteriormente, no De Legibus (Suárez unificou os tratados da Lei e do Direito). Essa primeira fase do pensamento suareziano pelo direito das gentes inicia-se com o seu magistério no colégio romano (1580-1585). Apesar desse contato precoce, o estudo da guerra corresponde, de modo paradoxal, tanto à mocidade intelectual de Suárez, como à sua maturidade. Ele foi pensado e redigido, na sua maior parte, em 1584, mas foi revisto e publicado somente em 1621. Esse lapso de tempo permitiu que a mensagem da obra não destoasse daquela do Tratado das Leis.

Assim, o jus gentium que o autor expõe no seu estudo sobre a guerra não consiste numa versão preliminar e ainda incompleta do seu pensamento final. Todavia, o Tratado da Caridade de Suárez possui uma finalidade muito diferente daquela do seu Tratado das Leis, e, dessa maneira, o direito das gentes cumpre uma função também bastante distinta. Mesmo antes da existência do que hoje denominamos de direito internacional, os juristas e padres buscavam minimizar os efeitos da guerra, limitar o seu alcance e estabelecer requisitos para a sua legitimidade. Esse corpo de ideias era universal por causa do seu fundamento: a religião cristã, que era aceita como a "Verdade" por todos os povos europeus. Entretanto, a Reforma Protestante alterou esse quadro de maneira drástica, e o próprio cristianismo passou a

4 Vide a obra BORGES DE MACEDO, Paulo Emílio. O nascimento do direito internacional. São Leopoldo: UNISINOS, 2009. 
apresentar versões. Em consequência, a teologia católica (inclusive a teologia político-jurídica) não poderia mais ser universalizada.

Este foi o desafio de Suárez: evitar que os preceitos da guerra justa se perdessem em meio ao relativismo. O jurista de Coimbra é um pensador da segunda vaga da escolástica espanhola; os grandes problemas da sua vida não são mais aqueles do tempo de Francisco de Vitória: as Grandes Navegações, a descoberta do Novo Mundo e o direito dos índios. Ele teve de lidar com a Reforma; foi o teólogo mais importante da Contra-Reforma. Quando o rei Jaime I obriga mais um juramento de fidelidade na Inglaterra (o que afastaria o poder do Papa mesmo em questões espirituais) e inicia uma polêmica com o Cardeal Belarmino, Roma recorre ao seu teólogo mais importante da época que eleva a discussão e escreve uma obra científica de mais de oitocentas páginas, a Defensio Fidei Catholicae adversus anglicanae sectae errores.

Então, se as verdades não fé não constituíam mais um terreno comum, o que impediria o relativismo de destroçar o direito da guerra?

\section{A questão herdada por Suárez}

A guerra justa representa a via mediana entre o repúdio total da guerra, como ocorre em correntes idealistas, e a aceitação incondicional da violência para o engrandecimento do Estado, segundo concepções próprias do realismo político, como se os reis e as potestades não se sujeitassem à Moral e às leis da natureza. Os partidários da guerra justa reconhecem que a guerra constitui um mal, mas há males ainda piores, como o assassinato de entes queridos e a profanação de cemitérios e lugares sagrados pelas mãos de soldados invasores. Trata-se de uma tradição universal: foi desenvolvida por teólogos e canonistas cristãos, mas também por juristas leigos.

A maioria dos historiadores credita as origens dessa doutrina ao jus fetiale do colégio dos fetiales romanos. Este corpus juris existiu desde os dias dos reis até o final da era republicana. Os feciais eram sacerdotes, reunidos em uma espécie de corporação, aos quais eram encarregados de uma série de obrigações, em parte religiosas e em parte jurídicas (o jus sacrum). Entre diversas obrigações, cuidavam daquelas relativas ao início de uma guerra. Duas condições de natureza processual revelavam-se indispensáveis: uma notificação oficial ao oponente, com uma insistência para a satisfação do dano ou da ofensa dirigida a Roma, acompanhada de um devido prazo de resposta, e uma declaração formal de guerra. Esta última ocorria numa cerimônia religiosa bastante elaborada, na qual se devia recitar, com uma impostação de voz adequada, 
determinadas fórmulas legais, e terminava com o arremesso de uma lança embebida em sangue na fronteira do território inimigo. Roma não podia entrar em guerra sem a aprovação prévia e explícita dos feciais, pois os deuses só favoreciam o bellum iustum et pium. Contudo, como eram subordinados aos chefes políticos, eles buscavam sempre uma justificativa para as hostilidades (v.g., a violação de um tratado ou da imunidade de embaixadores, infração de direitos territoriais ou ofensas contra Estados aliados) ${ }^{5}$.

A influência do direito dos feciais na doutrina da guerra justa, no entanto, revela-se tão elusiva que se torna difícil estabelecer uma correlação. O desenvolvimento posterior que ela recebe no Medievo pouco lembra as suas origens romanas. $\mathrm{O}$ direito de guerra medieval não denota formalismo algum, nem mesmo subserviência à autoridade política. De Roma, apenas parece haver sobrevivido a ideia de poder predicar-se a justiça ou a injustiça de determinados conflitos armados. As guerras não se apresentavam mais como acontecimentos naturais ou fatalidades e passaram a ingressar o domínio das ações moralmente relevantes.

Outros autores ${ }^{6}$ encontram, no direito de guerra medieval, influências dos hebreus do Antigo Testamento, e, de maneira inegável, é possível detectar reminiscências helênicas. Entretanto, parece haver um consenso de que se trata de uma doutrina especificamente cristã e que se inicia propriamente com Santo Agostinho (354-430). Influências anteriores são - como haveriam de ser - devidas, mas incidem de forma incidental no principal problema desta tradição: a justiça de uma guerra.

De questões meramente procedimentais com os antigos, a doutrina da guerra justa adquire uma conotação substantiva durante todo o Medievo. A guerra e toda a violência e a destruição que lhe advêm consistem num problema moral bastante sério para o cristianismo; além de os cristãos sempre se engajarem em contendas contra não-cristãos e, até mesmo, contra cristãos, os textos sagrados podem induzir ao erro. De um lado, há os ensinamentos de Cristo sobre a paz e "dar a outra face" aos inimigos, o que poderia gerar uma interpretação pacifista radical que rejeita qualquer guerra, mesmo aquelas defensivas; de outro, Deus revela-se o "senhor dos exércitos", o que poderia legitimar qualquer guerra santa.

5 Cf. FUSINATO, G. Le droit international de la République Romaine. RDILC - Revue de droit international et de législation comparée, pp. 273 e ss., 1885.

6 Cf. VANDERPOL, Alfred. La Doctrine Scolastique du Droit de Guerre. Paris: Pédone, 1919. pp. 160-170. 
Contudo, para o cristianismo, a guerra não representa um mal em si mesmo. Segundo os maestros espanhóis, os males que se sucedem pela guerra são acidentais à sua natureza, e haveria maiores inconvenientes se ela não fosse permitida ${ }^{7}$. Ademais, nenhum concílio proibiu os cristãos, de maneira definitiva, de participar de uma guerra. Há, sem dúvida, algumas restrições: o Concílio de Nicéia proscrevia o combate logo após o batismo; em Isaías, não se pode matar nem morrer sobre a montanha santa - e, por interpretação extensiva, lugares sagrados. A explicação dessa concepção decorre do fato de que a guerra não se opõe à paz, mas sim à má paz, aquela que perdura em detrimento da justiça e do direito. Existe uma diferença substancial entre os conceitos de paz e de tranquilidade. Esta é paralisia, a paz é harmonia. Harmonia sempre pressupõe um equilíbrio, a balança da justiça. Dessa feita, a "verdadeira" paz apoia-se no Direito.

A guerra justa corresponde a uma tradição eminentemente cristã, porque ela é desenvolvida e reelaborada por autores da cristandade europeia. Após a sua origem com Santo Agostinho, ela é retomada por outros Pais da Igreja, por Santo Isidoro de Sevilha e o Papa Nicolau I. Houve, então, um hiato, e a guerra justa não recebeu mais atenção durante a Alta Idade Média. Somente depois das teses serem condensadas no Decreto Gratiano, na metade do século XII, o assunto volta a interessar os pensadores. Escrever sobre a guerra torna-se bastante popular na Baixa Idade Média. Os canonistas e os teólogos começam a esmiuçar as teses até elas adquirirem a sua formulação clássica em Santo Tomás de Aquino. Em virtude do interesse do Aquinate, a guerra justa se torna referência obrigatória para todos os escolásticos. Por esse motivo, Alfred Vanderpol prefere denominá-la de a "doutrina escolástica do direito da guerra"s.

7 Cf. SUÁREZ, R. P. Francisci. Opera Omnia. Editio Nova. Parisiis: Ludovicum Vivès, 1858. Tomus XII. De Fide, Spe et Charitate. Tratactus de Charitate. Disputatio XIII. De Bello, 1, 2. Este texto será doravante chamado $D B$.

8 Cf. VANDERPOL, Alfred. Op. Cit., p. 285. São autores dessa tradição, além de Santo Agostinho, Santo Isidoro de Sevilha (560-636), o Papa Nicolau I, com a sua carta aos búlgaros, o bispo Rufin, no tratado De bono pacis (1056), Yves de Chartres (1040-1116) e Abelardo (1079-1142). Na metade do século XXII, há o decreto do monge Jean de Gratian. Então, surgem Santo Tomás, Raimundo de Peñaforte (1180-1275), Inocêncio IV (1243-1254), Hostiensis (Henri de Suse: início do século XXIII-1271), Alexandre de Halès (1170-1245), Henri de Gand (início do século XXIII-1293) e São Boaventura (1221-1274). Depois, no século XIV e $\mathrm{XV}$, passam a surgir obras cujos títulos remetam à guerra: João de Legnano (início do século XXIV-1383) - De Bello (1360), Henri de Gorychum - De Bello Justo (1420), Santo Antonio de Florença (1389-1459), Alphonse Tostate (1400-1455), Martin de Lodi - De Bello (século XV), Gabriel Biel (1425-1495), Sivestre Prierias (1456-1523), Thomas de Vio (Cajetan: 1468-1534), Guilherme Mathiae - Libellus de Bello Iustitia Iniustitiave (1533), Josse Clichthove (1472-1543). Depois, com as Grandes Navegações despontam os nomes de Francisco de Vitória, Francisco Suárez e Balthasar de Ayala - De Jure et Officiis Bellicis et Disciplina Militari (1582). Deste período, são nomes menores: A. Guerrero - Tratactus de Bello Justo et Injusto (1543), Diego de Covarruvias (1512-1577), Domingos de Soto (1494-1560), F. Martini - De Bello et Duello 
A Igreja, como instituição, nunca aceitou as teses de um pacifismo extremado. Os cristãos não cessavam de engrossar as fileiras das legiões muito antes dos Editos de Roma e de Milão. É a sua numerosa presença no exército que se tornaria a causa principal das últimas perseguições por parte dos romanos. E, como haveria de ser, nasce no exército o movimento que culminaria nos Editos de tolerância de Constantino e de Licinius de 313, os quais não consideraram pecado a profissão militar. A compatibilidade do serviço militar com o cristianismo era considerada tamanha que um dos Pais da Igreja, Santo Atanásio, chegou a pregar que, numa guerra justa, seria permitido e, até mesmo, glorioso, dar a vida ${ }^{9}$.

Ocorre que os primeiros escritos da guerra justa, em verdade, ocupavam-se da guerra apenas de modo secundário. $\mathrm{O}$ primeiro problema dos Pais da Igreja não foi com a guerra em si, mas com a legitimidade de uma função pública, o serviço militar, em face da moral cristã. Dessa maneira, as afirmações de Santo Agostinho consistem numa manifestação tardia dessa preocupação. Na célebre passagem do Contra Faustum manichaeum, em que ele defende a campanha de Moisés contra as investidas de Faustus de Milev, a guerra não constitui a questão central, mas a obediência incondicional às ordens divinas, insondáveis, porém justas: "não se deve estranhar ou se horrorizar ante o fato de Moisés ter empreendido guerras, porque não o fez por crueldade, mas por obediência e respeito às ordens divinas" 10 .

No De civitate Dei, a guerra torna-se alvo de críticas porque representa um dos principais instrumentos do imperialismo romano. Santo Agostinho a usa como cavalo-de-batalha dentro da luta maior contra os falsos valores cantados por Virgílio: a grandeza ilusória de Roma resulta da superbia, não da pietas. O célebre verso do poeta figura no prefácio mesmo do livro ${ }^{11}$. De fato, a crítica de Agostinho não se volta contra a guerra em si, mas contra toda a moral pagã. É a partir da pax e da noção conexa de ordo naturalis que se estabelece a unidade de sua concepção. Tal como em sua Teodicéia, em que o mal se reduz a uma ausência do bem, sem possuir uma consistência própria, a guerra

(1589), Gabriel Vasquez (1551-1604), Domingos Bañez (1528-1604), Roberto Berlarmino (1542-1621), Leonardo Lessius (1554-1623), Gregório de Valencia (1561-1603), Luís de Molina (1536-1600), P. Belli - De re Militari et Bello (1558), Alberico Gentili - De Jure Belli (1598) e o próprio Hugo Grócio - De Jure Belli ac Pacis (1625).

9 Cf. NYS, Ernest. Les Origines du Droit International. Bruxelles, Paris: Alfred Castaigne, Thorin et fils, 1894. p. 45.

10 “(...) nec bella per Moysen gesta miretur aut horreat, quia et in illis divina secutus imperia non saeviens, sed oboediens fuit (...)" (AGOSTINHO. Obras de San Agustin. Trad. Pío de Luis. Edição bilíngüe. Madrid: BAC, 1993. t. XXXI. Escritos antimaniqueos. Contra Fausto. p. 604. Livro XXII. 74).

11 Cf. AGOSTINHO. Obras de San Agustin. Trad. José Moran. Edição bilíngüe. Madrid: BAC, 1958. t. XVI. La Ciudad de Dios. p. 62. Livro I. Praefatio. 
não passa de uma idéia reflexa dos conceitos positivos de pax e ordo. A vontade humana é livre para se submeter à ordo, pela pietas, ou de se opor a ela pela superbia. A pietas conduz à pax ordinata que está em harmonia com a ordo naturalis; a superbia leva à pax perversa, a paz da cidade diabólica. A guerra para ser justa deve cindir este tipo de paz e construir uma melhor, mais adequada à ordo naturalis, o que corresponde à vontade divina ${ }^{12}$.

Como reação à avidez feudal pelo combate, a Igreja iria posicionarse contra a guerra. Contudo, a sua hostilidade resumia-se à guerra entre fiéis. Procurava-se reduzir a violência e a destruição da guerra. Proibiram-se os clérigos de derramar sangue. Um concílio impôs aos companheiros de Guilherme, o Conquistador uma penitência de um ano para cada pessoa assassinada, outra de quarenta dias por aqueles feridos e outra ainda de três dias por aqueles que se desejou ferir. Cumpre salientar que não se questionava a legitimidade da guerra em si; apenas a guerra injusta era considerada um verdadeiro castigo de Deus ${ }^{13}$.

Os historiadores costumam considerar o livro XVIII das Etimologias de Santo Isidoro de Sevilha uma referência obrigatória na Alta Idade Média. O autor distingue quatro espécies de guerra: justum bellum, injustum bellum, civile bellum e plusquam civile bellum (aquela entre generais unidos por laços de família). "Justa é a guerra que é declarada para reaver coisas que tenham sido subtraídas ou para repelir os inimigos". E, por sua vez, "injusta é a guerra que provém de um furor e que não foi iniciada por uma razão legítima"14. Nesta definição, há, portanto, dois requisitos para a justiça de uma guerra: uma declaração e uma causa justa. Esta pode ser a repulsa de um inimigo, o que caracteriza uma guerra defensiva, ou a vindicação de um bem roubado, uma espécie do gênero maior da injúria.

Não obstante a importância que essa definição iria adquirir posteriormente - sobretudo porque seria reproduzida no Decreto Gratiano -, o jurista suíço Peter Haggenmacher ressalta que essa fórmula representava um lugar-comum da literatura antiga e não era propriamente nuclear à tradição da guerra justa. Ele demonstra, em sua tese, que o bispo de Sevilha desejava retomar duas frases de Cícero, não

12 Cf. TRUYOL y SERRA, Antonio. El Derecho y el Estado em San Agustin. Madrid: Revista de Derecho Privado, 1944. pp. 57-70.

13 Cf. NYS, Ernest. Op. Cit., p. 46.

14 "Justum bellum est quod ex praedicto geritur de rebus repetitis aut propulsandorum hostium causa". E "Iniustum bellum est quod de furore, non de legitima ratione inititur". (ISIDORUS HISPALENSIS EPISCOPUS. Etymologiarum sive Originum Libri XX. ed. W. M. Lindsay. Oxford: Clarendon Press, 1911. XVIII, De bello et ludis, I, 2). 
o pensamento de Santo Agostinho sobre a guerra ${ }^{15}$, o qual teria pouca ou mesmo nenhuma repercussão nesse período. Cumpre salientar que o mesmo não se aplica às noções agostinianas de pax e iustitia, as quais integram o cerne do agostinianismo político. A concepção cristã de justiça enraíza-se no Ocidente, desde o fim do Império, graças à função privilegiada que diversos papas desempenhariam na organização política dos monarcas francos e germânicos.

Somente no século XII, a doutrina da guerra justa começa a se consolidar. Em Bolonha, no ano de 1140, o monge Graziano redige a Concordia discordantium canonum que marca o início do direito canônico clássico. A guerra constitui objeto de uma porção substancial da obra, a Causa XXIII, e, desde então, torna-se tema obrigatório para as futuras gerações de teólogos e canonistas. O Decreto Gratiano mostrase uma obra tanto de Direito como de Teologia, o que o deixa suscetível a variadas interpretações. Consiste numa consolidação sobre diversos temas - entre os quais a guerra - na qual Graziano reúne uma gama de referências da Patrística. Todas as passagens que são tradicionalmente associadas com a doutrina da guerra justa se encontram num mesmo local. Se a razão assistir a Haggenmacher - e tanto Agostinho como Isidoro não houverem debruçado-se sobre a guerra justa -, então éa partir do Decreto que começa essa tradição. O simples fato de codificar todo o pensamento cristão sobre a guerra já denota a pretensão de investigar este tema por ele mesmo. As citações foram retiradas do seu contexto original e passaram a valer por elas mesmas, como uma regra universal. Trata-se de uma atitude mais genérica, característica do pensamento do período em face das auctoritates: nestas, deve sempre buscar-se normas de caráter geral, sem nem mesmo atentar para o conjunto maior em que se inseriam. Graziano chega, inclusive, a assimilar os trechos da Patrística às decisões dos concílios e aos decretais dos papas: todos correspondem a cânones ${ }^{16}$.

A causa XXIII do Decreto Gratiano intitula-se De re militari et bello e divide-se em oito questões. A primeira questão aborda, de maneira direta, fato inédito, a moralidade das guerras em si mesmas: an militare sit peccatum? ("é pecado fazer a guerra?"). Apesar de invocar diversos preceitos do Evangelho que recomendam a doçura e proíbem

15 Perceba-se a profunda semelhança com as frases de Isidoro: "Illa iniusta bella sunt, quae sunt sine causa suscepta. Nam extra ulciscendi aut propulsandorum hostium causa bellum geri iustum nullum potest. (...) Nullum bellum iustum habetur, nisi denuntiatum, nisi dictum, nisi de repetitis rebus". (CICERÓN. De la République - Des Lois. Trad. Charles Appuhn. Edição bilíngüe. Paris: Garnier Frères, 1954. p. 164. Livro III, 23). Confira também HAGGENMACHER, Peter. Grotius et la doctrine de la guerre juste. Genève, Paris: Heige, Presses Universitaires de France, 1983, p. 23.

16 Cf. HAGGENMACHER, Peter. Op. Cit., pp. 24-25. 
a vingança, o autor admite que a guerra pode ser legítima. Algumas guerras revelam-se necessárias, e essa necessidade acaba por escusar a violência ${ }^{17}$.

No entanto, a necessidade não basta para conferir legitimidade a uma guerra. Graziano empresta do tratado de Santo Agostinho contra os maniqueístas uma enumeração de todas as coisas repreensíveis num conflito: o desejo de destruir, a crueldade da vingança, o espírito implacável e violento, a selvageria no combate, a paixão de dominar e todos os outros excessos semelhantes. Engajar-se numa guerra, por si só, não equivale a um pecado, mas a mesma não deve ser conduzida com crueldade e cupidez, e sim com a finalidade de buscar a paz. Há, no decreto, duas definições de guerra justa, aquela de Isidoro de Sevilha, já citada, e outra emprestada de Santo Agostinho: “Tem-se o costume de chamar de guerra justa aquelas cuja finalidade é vingar as injustiças, ao castigar uma cidade ou um país que não puniu uma ação ilícita cometida por um dos seus, ou ao restituir aquilo que foi tomado de modo injusto". ${ }^{18}$ Portanto, justa é a guerra cuja finalidade é a busca da paz, que vinga uma "in-júria" e que restitui um bem tomado injustamente.

Cumpre salientar que, quando Graziano retoma a definição do bispo de Sevilha, introduz uma sutil modificação. Ele substitui a expressão ex praedicto, que implica a necessidade de uma declaração, por ex edicto, o que pressupõe a existência de uma autoridade que ordene que se faça a guerra ${ }^{19}$. Assim, de modo não muito expresso, começa a se formar a noção - que iria ser desenvolvida posteriormente por São Raymundo de Peñaforte e Santo Tomás de Aquino - de que a guerra justa requer a promulgação de uma autoridade legítima.

Embora no Decreto Gratiano a guerra seja, de fato, analisada em si mesma, ressalta Haggenmacher que a finalidade de Graziano não parece ter sido investigar a justiça na guerra. Se a causa XXIII for considerada como um todo, então o tema maior se revela como a legitimidade do poder coercitivo entre cristãos, no domínio da fé. A guerra consiste num dos modos de exercício desse poder. As três primeiras questões que versam sobre a guerra são as mais breves, em especial a própria questão que conceitua guerra justa. As duas questões medianas recebem, pela amplitude, a maior atenção, e são consagradas ao poder vindicativo e à sua última conseqüência, a pena capital infligida por um juiz. $\mathrm{O}$

17 Cf. GRATIANUS. Decretorum Codex. Venetiis: Nicolai Jenson Sallici, 1477. Causa XXIII, I, 1 .

18 "Iusta enim bella definiri solent, quae ulciscuntur injurias, si gens vel civitas plectenda est quae, vel vindicare neglexerit quod a suis improbe factum est, vel reddere quod per injurias ablatum est". (GRATIANUS. Decretorum Codex. Causa XXIII, II, 1).

19 Cf. NYS, Ernest. Op. Cit., p. 100. 
poder coercitivo, portanto, corresponde ao centro do problema. As três primeiras questões possuem um caráter preliminar e descartam uma objeção fundamental, as duas medianas versam sobre o assunto mesmo, a sexta e a sétima tratam das conseqüências imediatas da repressão, e a oitava aborda um questão particular, o emprego de armas pelos clérigos. Esta interpretação da causa XXIII também é corroborada pela história, pois foi adotada pelos principais decretistas do século XII nos seus comentários $^{20}$.

Ainda assim, mesmo que a causa XXIII não encerre uma doutrina da guerra justa, em virtude das especificidades de sua composição abordar a guerra em si e reunir uma massa de referências patrísticas sobre o assunto - ela representa um dos agentes mais decisivos para a sua emergência. De Graziano a Santo Tomás de Aquino, a doutrina da guerra desenvolve-se de maneira orgânica e contínua. Se, nos Pais da Igreja, a temática era tratada de passagem e se, no Decreto Gratiano, ela se insere num tema maior, entre os legistas, os canonistas e os decretalistas, ela conquista autonomia.

Merece destaque, na primeira metade do século XIII, a coleção de decretais que um dominicano espanhol, São Raymundo de Peñaforte, sob as ordens do Papa Gregório IX, reuniu. Nela, o autor estabelece cinco requisitos para a guerra justa (persona, res, causa, animus e auctoritas), os quais, mais tarde, serão condensados por Santo Tomás em apenas três. Pouco depois, dois outros autores produzem seus comentários aos decretais gregorianos: o Papa Inocêncio IV, um dos maiores juristas a ocupar o assento de Pedro, no Apparatus in quinque libros decretalium, e Henri de Suse, conhecido como Cardinalis Hostiensis, na Summa Áurea ${ }^{21}$.

Então, entre 1263 e 1269, Santo Tomás de Aquino redige a sua Suma Teológica e confere a formulação clássica da doutrina da guerra justa. Sua obra exerceria influência sobre teólogos, moralistas e, embora o Aquinate não fosse jurista, também sobre canonistas. A sua investigação acerca da guerra encontra-se condensada na questão 40 da secunda secundae do Tratado da Caridade, e ela se resume a quatro artigos. O primeiro versa sobre o problema da licitude da guerra; o segundo indaga se acaso seria lícito aos clérigos guerrear; o terceiro questiona tanto se seria legítimo aos combatentes usar de estratagemas, como se seria legal combater em dias festivos. Mas é no primeiro artigo mesmo que se encontra o cerne de sua concepção. Para haver justiça numa guerra, é necessário preencher três condições: 
Primeira, a autoridade do príncipe, por cujo mandato se permite fazer a guerra. Não cabe à pessoa privada declarar guerra, porque pode expor seu direito perante um tribunal superior. (...).

Requer-se, em segundo lugar, justa causa, a saber: que aqueles que são impugnados mereçam, por alguma culpa, essa impugnação. (...).

Terceiro, requer-se que seja reta a intenção dos combatentes: que se intente ou se promova o bem, ou que se evite o mal. (...).

Em razão da autoridade que o pensamento de Santo Tomás iria adquirir com o tempo, estas três condições passam a caracterizar a doutrina escolástica da guerra justa ${ }^{22}$.

Em razão da autoridade que o pensamento de Santo Tomás iria adquirir com o tempo, estas três condições passam a caracterizar a doutrina escolástica da guerra justa.

Cabe observar que juristas leigos também voltam os seus interesses ao direito da guerra. No final do século XIII, a questão é analisada por Cino de Pistóia e diversos juristas franceses da escola de Orléans. No início do século seguinte, reforça a doutrina o grande jurista medieval Bártolo de Sassoferrato, que incorpora as teses de Inocêncio IV. Um discípulo de Bártolo, Iohannes de Lignano, em 1360, escreve a primeira obra a tratar exclusivamente do direito da guerra: Tratactus de bello, de represaliis et de duello. Lignano inicia uma tradição que irá culminar em Gentili e Grócio. Este livro adquire uma conotação bastante prática porque sofreria diversas vulgarizações, como a de Christine de Pisan, William Caxton e o famoso trabalho de Honoré Bonnet, L'Arbre des Batailles, todas redigidas em idioma vulgar. A partir de então até a época de Grócio, começam a surgir obras que versam especificamente sobre o direito da guerra, como os tratados de Martin de Lodi, Juan Lopes, Pierino Belli, Balthasar Ayala e Heinrich Bocer. Ocorre, pois, uma progressiva consolidação do corpo doutrinário da guerra justa ${ }^{23}$.

Embora o livro de Lignano consolide de uma vez a doutrina da guerra justa, ele nada mais faz do que compilar as conclusões de seus

22 "Primo quidem, auctoritas principis, cuius mandato bello est gerendum. Non enim pertinet ad personam privatam bellum movere: quia potest ius suum in iudicio superioris prosequi. (...) Secundo, requiritur causa iusta: ut scilicet illi qui impugnantur propter aliquam culpam impugnationem mereantur. (...) Tertio, requiritur ut sit intentio bellantium recta: qua scillicet intenditur vel ut bonum promoveatur, vel ut malum vitetur". (AQUINO, Santo Tomás de. Suma Teologica. Texto latino de la edición crítica Leonina. Trad. Francisco Barbado Viejo, O.P. 2. ed. Madrid: Biblioteca de Autores Cristianos, 1947. 2-2 q. 40 a.1).

23 Cf. HAGGENMACHER, Peter. Op. Cit., pp. 39-40. 
predecessores. Ele introduz um período de estagnação na disciplina, dominado por uma casuística bastante estéril, à exceção de alguns progressos isolados - como o de um Lucas de Penna ou o de um Raphael Fulgosa. A partir do século XVI, ainda que o interesse só tenha aumentado, não serão os juristas a desenvolver o direito de guerra, mas os teólogos. Haggenmacher menciona as contribuições de Martinho Lutero e de Erasmo ${ }^{24}$, mas elas se apresentam um tanto excêntricas à tradição da guerra justa. Os principais escritores desse período acerca do tema são mesmo o italiano Thomas de Vio - vulgo Cajetano - e os escolásticos espanhóis. Entre estes, não há dúvidas, Francisco Suárez ocupa uma posição de destaque.

\section{O propósito do De Bello}

Cumpre salientar que, embora o objeto analisado consista no "direito" de guerra - um jus -, esse estudo se insere no Tratado da Fé, da Esperança e da Caridade - em especial, neste último. Pode parecer estranho ao leitor atual que um livro sobre uma das três virtudes teologais contenha um trabalho sobre um dos ramos do Direito; entretanto, para Suárez, isso não fugia à normalidade: só a caridade supre as limitações da justiça e do Direito. Ainda que se busque determinar a justiça, a guerra constitui uma realidade que perpassa este domínio e acaba em outro.

É que havia questões jurídicas para as quais o Direito não possuía resposta. Na Idade Antiga, o cético Carneades direcionou seus ataques contra a doutrina da lei natural dos estoicos. Ele granjeou fama, com o seu método de demonstração dos prós e dos contras, ao ridicularizar a noção de justiça. Um dos seus argumentos mais célebres foi o caso limítrofe que ficou conhecido como o "paradoxo de Carneades". Num naufrágio, duas pessoas nadam até uma tábua para se salvarem, mas ela só comporta uma. Quem, neste exemplo, tem o direito à tábua? Num caso extremo de necessidade e de autopreservação, segundo o cético, a resposta seria, ao mesmo tempo, ninguém e ambos. Hoje, os ordenamentos jurídicos encerram a figura do "estado de necessidade" para situações como essa, e qualquer um dos náufragos poderia tomar a tábua para si e ainda se encontraria ao abrigo dessa excludente de ilicitude. Mas essa resposta não satisfaria um antigo, pois se acreditava que a justiça poderia assistir apenas a um. Assevera Rommen ${ }^{25}$ que, somente dezessete séculos depois, Suárez daria a solução correta. O Direito não pode funcionar em situações de extrema escassez ou

24 Cf. HAGGENMACHER, Peter. Op. Cit., p. 42.

25 Cf. ROMMEN, Heinrich. The Natural Law. Tradução para o inglês de Thomas Hanley. Indianápolis: Liberty Fund, 1998, p. 18. 
absoluta abundância de bens, pois pressupõe distribuição. No exemplo citado, a ordem da justiça e do Direito termina e se inicia o governo da caridade.

Em Santo Tomás, a paz corresponde a um efeito interior em consequência à caridade. A guerra, por sua vez - em conjunto com o ódio, a acídia, a envídia, a discórdia, a porfia, o cisma, a rinha, a sedição e o escândalo -, é um vício contrário à caridade. Para um teólogo, determinar a justiça numa guerra importa não tanto para aferir a injúria, mas porque constitui um pecado contra uma das três virtudes teologais. A investigação da justiça ou da injustiça de uma guerra é um meio para um fim de natureza teológica muito mais importante. Uma guerra injusta, além de ferir o Direito, fere a caridade. Francisco Suárez repete essa mesma ordem e não aborda o direito da guerra no tratado em que ele discorre sobre as leis e a justiça, o De Legibus, mas na última disputatio do Tratado sobre a Fé, a Esperança e a Caridade. É assim que um teólogo estuda o Direito.

Nas disposições concretas e específicas sobre o direito da guerra, o autor não se mostra muito original; em seu texto, ele sintetiza todos os trabalhos da segunda escolástica sobre a guerra justa. Este foi o seu mérito e o seu intento. Trata-se, sobretudo, de uma concepção católica e espanhola. Ainda assim, causa espanto o fato de, desde Francisco de Vitória, os maestros espanhóis pregarem uma tolerância muito grande com outros povos e religiões - sobretudo a muçulmana - e reprovarem a sede de conquista ibérica. Suárez, por exemplo, não hesita em admitir a possibilidade de justiça numa guerra de um soberano não cristão contra um príncipe cristão. Segundo Vitória, visto que a autoridade decorre não da religião, mas da natureza, todos os povos, mesmo os infiéis, possuem títulos válidos de domínio. Os índios, portanto, também exercem soberania e se encontram em "domínio pacífico de suas coisas públicas e privadas. Logo (salvo outro óbice em contrário), devem ser considerados verdadeiros senhores e, nessas circunstâncias, não se pode despojá-los de suas posses"26. Dessa forma, o direito de guerra da Escolástica Espanhola obstrui os títulos de propriedade dos espanhóis na América e retira dos monarcas católicos o monopólio da justiça.

De fato, à primeira vista, a "escola espanhola da paz" (termo empregado por Luciano Pereña) parece pouca espanhola e pouco católica.

26 "(...) in pacifica possessione rerum et publice et privatim. Ergo omnino (nisi contrarium constet) habendi sunt pro dominis. Neque in dicta causa possessione deturbandi" (VITORIA, Francisco de. Obras de Francisco de Vitória. Relecciones Teologicas. Editadas por Teofilo Urdanoz. Madrid: Biblioteca de Autores Cristianos, 1960, De Indis, Relectio 1, 5. p. 651). 
Contudo, a "hispanidade" e a "catolicidade" representam muito mais do que a mera defesa de uma política de Estado ou de uma concepção de mundo ultrapassada. O grande dilema do século XVI mostra-se a dissociação inexorável entre as duas cidades, a terrena e a de Deus. Todo o esforço intelectual de Suárez é o de combater Maquiavel nos seus próprios termos. A ideia de Império havia perdido lastro com os tempos históricos, e existiam tantas soberanias como o número de Estados. A Espanha, para o autor, constituía a chave da crise e a última esperança de reconstrução da cristandade europeia. Ela deveria converter-se no império a serviço da religião, da justiça e da civilização. Todos os príncipes católicos, por imperativo da fé, podiam proteger a Igreja. Mas somente um Estado grande e forte, como a Espanha, conseguiria se insurgir contra o cisma da terra e salvar a civilização cristã ${ }^{27}$.

Para uma verdadeira missão civilizatória - uma empresa que precisava ser tanto católica como espanhola -, Suárez concebeu o De Bello. E, se ele parece pouco católico e pouco espanhol, é porque ele deve ser lido à luz do capítulo dezoito do Tratado sobre a Fé, que Luciano Perenã denomina de o "Tratado da Intervenção". Ele versa sobre os meios justos de coação para converter os infiéis, e sua principal mensagem resume-se ao dever dos pagãos de ouvir e tolerar a fé cristã ${ }^{28}$. Não se trata de uma obrigação de conversão - a qual pressupõe uma adesão livre -, mas de suportar a evangelização. A religião católica encerra a Verdade, e não se pode impedir a sua divulgação. A fim de garantir a pregação, o papa pode comissionar os príncipes católicos para intervirem e promoverem a guerra. Dessa maneira, o projeto da segunda escolástica termina sim por justificar a política imperial espanhola tanto na conquista da América como da Ásia.

Ainda assim, isso representa um avanço considerável em relação à visão anterior sobre "os bárbaros a circundar o Império cristão e europeu". A soberania e os títulos de domínio dos infiéis não se apresentam inferiores aos dos cristãos. A política dos povos pagãos possui o mesmo valor daquela dos que professam a verdadeira fé. A lição da separação das duas cidades foi bem aprendida. Porém, Suárez sabia bem que, sem a ação do Direito (bem como da Caridade), essa dissociação resultaria no relativismo ético e na falta de religião. Se a defesa da cristandade europeia não podia mais se fazer nos moldes antigos, tampouco a civilização, todos aqueles séculos de uma cultura centrada na razão e na

27 Cf. PEREÑA, Luciano. Estudio Preliminar. In: SUÁREZ, Francisco. Guerra Intervención Paz Internacional. Tradução para o castelhano de Luciano Pereña. Madrid: Espasa-Calpe, 1956. p. 10.

28 Cf. PEREÑA, Luciano. Estudio Preliminar. In: SUÁREZ, Francisco. Guerra Intervención Paz Internacional. pp. 19 e ss., bem como toda a segunda parte da obra, intitulada El Derecho de Intervención. 
emancipação do homem, podia ficar sem abrigo. O direito da guerra e o jus gentium em geral, pois, constituem valiosos instrumentos na luta da civilização contra a barbárie.

Dessa feita, o De Bello dirige-se aos moralistas para a formação das suas consciências. Este, portanto, constitui o motivo do caráter casuístico do estudo e de sua localização no Tratado da Caridade. O tom e a destinação consistiam numa resposta a Alberico Gentili para quem o estudo da guerra não integra o ofício do moralista ${ }^{29}$. Este escritor, em outro trecho, ao passar por cima de todas as sutilezas dos escolásticos, havia asseverado que a justiça de uma guerra não guarda relações com a religião, como se eles houvessem esposado posição tão rudimentar. Gentili termina essa observação com a famosa advertência: "Teólogos, em coisas que não vos dizem respeito, calai!"30 Trata-se de uma resposta à afirmação de Vitória, descrita anteriormente, acerca da hipertrofia da função do teólogo. Não há dúvidas de que Francisco Suárez não poderia deixar de reafirmar a concepção da escola espanhola em face de tão grosseiro ataque do jurista italiano de Oxford. $\mathrm{O}$ direito de guerra escolástico não era um mero panfleto de defesa do catolicismo. Tratava-se de um edifício teórico sofisticado e repleto de nuanças que identificava a justiça na guerra não com a religião, mas com a civilidade entre os povos. A grande sutileza, que se revela de difícil percepção, é o fato de que se identifica civilização com as religiões monoteístas e, em especial, com o cristianismo.

Isso requer explicação. Para regular o fenômeno da guerra, não se contava apenas com princípios decorrentes da natureza. Embora boa parte do direito da guerra se circunscrevesse à lei natural, havia algumas práticas que escapavam a esse domínio. Os códigos de cavalaria e a honra militar, bem como alguns procedimentos em relação aos despojos e à captura de nobres - normas positivas, portanto - eram reconhecidos como vinculantes. Escrever sobre a existência de um sistema jurídico de preceitos aplicáveis a todos os povos equivalia aceitar a ideia de um direito natural. No entanto, demonstrar a validade de um corpo jurídico de normas bastante precisas e concretas, em especial com vigência numa situação tão extrema como a guerra, significava defender um direito positivo comum. Além disso, esse direito não poderia mais ser o direito romano medieval: a própria decadência deste e a descoberta de povos não europeus - os quais nunca conheceram aquele direito - impediam isso.

29 Cf. GENTILI, Alberico. De Iure Belli Libri Tres. Hannover: G. Antonius, 1612. Disponível na internet em <http://gallica.bnf.fr $>$. Acesso em julho, 2012, I, 1, 1.

30 "Silete theologi in munere alieno!" (GENTILI, Alberico. Op. Cit. I, 12, 4). 
Ainda que muitas normas de direito da guerra pertencessem ao direito positivo - e a sua aplicação ultrapassasse os limites da lei civil -, isso não implicava a sua validade universal. No século XIII, distinguiamse quatro tipos diferentes de guerra, cada qual com regulamentação própria, de acordo com a sua natureza e com o inimigo ${ }^{31}$. Com a separação das duas cidades e a descoberta dos povos americanos, o direito da guerra corria o sério risco de nunca se tornar universal. Poderia conservar-se a existência de guerras diferentes, cada qual com as suas normas, conforme o contendor. Nem todos os preceitos deste ramo eram morais; portanto, escapavam à lei natural, universal por excelência. A maneira pela qual os teólogos espanhóis conseguiram universalizar esse direito foi a de encontrar regras racionais que pudessem propiciar a paz. É possível compreender o direito de guerra da segunda escolástica como uma justificativa tanto da política externa da Espanha, quanto da expansão cristã. Mas também é possível compreendê-lo como um esforço para propagar a civilidade. Como não se podia mais universalizar a religião, universalizou-se a civilização. Cabe observar que a civilização que se conhecia florescia dos valores cristãos e europeus. Mas era esta a alternativa ao relativismo.

\section{A reinterpretação de Santo Tomás}

O Doutor Exímio - parece evidente - não menciona de forma expressa os termos "civilização" ou "civilidade", mas eles correspondem ao sentido geral de todas as suas prescrições casuístas em direito da guerra. É a opção clara por uma ótica que perpassa o Direito e atinge a caridade que possibilita ao autor universalizar noções que não possuem um teor exclusivamente moral. A fim de que se possa perceber isso, faz-se necessário um exame mais detalhado desses preceitos. Suárez principia a sua obra ao fornecer um conceito bastante operacional de guerra: "a luta exterior que se opõe à paz externa se chama propriamente guerra, quando se estabelece entre dois soberanos e dois Estados" 32 . Essa definição, embora curta, desvela algumas noções fundamentais para quem estuda a guerra do ponto de vista da caridade. O fato de

31 Eram elas: a guerre mortelle, também chamada de "guerra romana" na qual não se faziam prisioneiros, nem se aceitavam os resgates. Ocorriam, em geral, contra não-cristãos. Já o bellum hostile se dava entre cristãos e se reconhecia diversas regras de civilidade: limites aos maus tratos, o resgate de nobres prisioneiros, etc. A guerre couverte acontecia entre dois nobres vassalos ao mesmo suserano. Não havia restrições em relação à morte do inimigo, mas a propriedade deveria ser resguardada. Além dessas três formas, existia ainda o cerco, que pela sua natureza, encerrava preceitos próprios. (Cf. STACEY, Robert. The Age of Chivalry. In: HOWARD, Michael; ANDREOPOULOS, George, e SHULMAN, Mark (org.). The Laws of War: constraints on warfare in the Western World. New Haven, London: Yale University Press, 1994. pp. 32-39).

32 "Pugna exterior, quae exteriori paci repugnat, tunc proprie bellum dicitur, quando est inter duos principes, vel duas respublicas" (SUÁREZ, Francisco. DB, Proemium). 
a guerra consistir numa luta exterior que se opõe a uma paz externa contrapõe-se a perturbações da alma, por conseguinte, interiores. A guerra corresponde a um vício social, não individual, o que a distingue de diversas outras corrupções da paz. Ainda, por constituir uma luta entre Estados, a guerra se diferencia da sedição (o combate entre o soberano e o seu povo) ou da rixa e do duelo (entre particulares).

O primeiro problema que Suárez precisa enfrentar refere-se à ideia de que a guerra poderia ser intrinsecamente má. Isso pode destroçar toda a construção da guerra justa. Correlata a esta questão, encontra-se a objeção sobre se não há algum óbice ao cristão de fazer a guerra. $\mathrm{O}$ teólogo granadino precisa determinar, pois, se a guerra não se contrapõe primeiro à natureza humana e depois à religião cristã. Ele se vale, portanto, de diversas passagens bíblicas, que já constavam do Decreto Gratiano, para demonstrar que Deus não quis proibir a guerra. E, naqueles trechos em que parece haver uma condenação, Suárez mostra que se dirigia a crítica a outra circunstância, não à guerra em $\mathrm{si}^{33}$.

Além de lícita, há situações em que a guerra é obrigatória, sob a ótica da caridade. Nas guerras defensivas, todos aqueles que podem combater possuem o dever de defender a pátria. Tampouco a guerra agressiva consiste num mal em si mesmo. Este tipo de guerra, para Suárez, não corresponde a uma expansão imperialista. A diferença entre a guerra defensiva e a agressiva reside na injúria. Quando esta se encontra em curso, a resposta do outro Estado toma a forma de uma guerra defensiva; quando já se perfectibilizou, a de uma guerra agressiva $^{34}$. Dessa feita, nenhuma guerra em si mesma, quer seja defensiva ou agressiva, atenta contra a natureza ou o Evangelho.

Como haveria de ser, Suárez retoma as três condições de justiça numa guerra de Santo Tomás: "primeiro, poder legítimo para fazer a guerra. Segundo, uma causa justa ou um título jurídico. Terceiro, que se observe um modo digno e a equidade no começo da luta, durante as hostilidades e depois da vitória" ${ }^{35}$. Fora desses requisitos, deve condenarse a guerra porque, embora não constitua um mal em si mesma, ela traz consigo diversos males. A morte e destruição que toda guerra encerra precisam ser justificados por um bem maior. Isso não significa a adesão à máxima de que "os fins justificam os meios". Contudo, alguns fins justificam sim alguns meios. Todo o objetivo do restante da obra

33 Cf. DB. $1,2$.

34 Cf. DB. 1, 3-5.

35 "Primum, ut sit a legitima potestate. Secundum, ut justa causa, et titulus. Tertium, ut se vetur debitus modus, et aequalitas in illius initio, prosecutione, et victoria" (DB. 1, 7). 
vai ser o de aferir quais fins e quais meios são esses. Perceba-se que o autor modifica um pouco a última condição da "intenção reta" do Aquinate. Como a guerra versa sobre as ações exteriores, pode perceberse a intenção reta somente pelo comportamento dos contendores na condução das hostilidades.

Suárez passa a analisar, pois, a primeira condição. Como qualquer pessoa se encontra autorizada pelo direito natural a se defender, o problema da autoridade legítima não abrange as guerras defensivas, somente as agressivas. $\mathrm{E}$ a autoridade repousa naquele que detém a soberania. Cumpre salientar que, se o soberano não se manifesta, a decisão retorna ao povo ${ }^{36}$.

A guerra deve ser declarada pelo soberano, primeiro, porque cabe a ele a defesa do Estado. Segundo, porque essa faculdade (a de declarar guerra) integra o poder de jurisdição. Seu exercício pertence à justiça vindicativa, "de máxima necessidade numa república para castigar os malfeitores. Assim, como o chefe do Estado pode castigar a seus próprios súditos quando fazem mal a outro, pode também vingarse de outro soberano cujo Estado lhe ficou sujeito em razão de um delito" ${ }^{37}$. A jurisdição do soberano incide sobre os seus súditos, porque estes integram o seu povo, mas se estende a um terceiro Estado em decorrência de um delito. Trata-se de uma concepção penal da guerra: esta representa uma espécie de sanção criminal. Como não há um juiz superior aos dois príncipes que possa julgar a contenda, e se quem ofende não quer reparar, a guerra constitui o único meio possível.

Num sistema jurídico primitivo, a autotutela parece consistir na única maneira de se fazer justiça. É uma forma defeituosa, mas possível de realizar a justiça. "O que faziam os juristas e teólogos do século XVI senão acomodar a uma circunstância histórica os princípios imutáveis e eternos da justiça e do direito natural?" 38 Atente-se ao fato de que a lei natural concede a todos os indivíduos o direito de se defender, mas não o poder de jurisdição. Essa é a razão pela qual os particulares podem sempre se defender, mas nunca declarar uma guerra. Em Suárez, não existe analogia possível entre a guerra e a rusga do particular.

A causa justa para uma guerra corresponde sempre a uma injúria

36 Cf. DB. 2, 1.

37 “(...) quae maxime necessaria est in republica ad coercendum malefactores; unde sicut supremus princeps potest punire sibi súbditos quando aliis nocent, ita potest se vindicare de alio principe, vel republica, quae ratione delicti ei subditur" (DB. 2, 1).

38 "Qué hacían los juristas y teólogos del siglo XVI sino acomodar a una circunstância histórica los principios inmutables y eternos de la justicia y el derecho natural?" (PEREÑA, Luciano. Estudio Preliminar. In: SUÁREZ, Francisco. Guerra Intervención Paz Internacional. p. 46). 
bastante grave, que não se pode vingar nem reparar de outra forma. Em princípio, a conservação própria e de seus direitos justifica o combate. Porém, faz-se necessário que o delito seja bastante sério: os motivos que os pagãos levantam (a ambição, a avareza, a vanglória e a ostentação) não servem, porque qualquer Estado pode invocá-los, o que conduziria ao absurdo de existir uma guerra justa para ambos os lados ${ }^{39}$. Há três classes de injúrias graves. A primeira ocorre quando um príncipe se apodera das propriedades do outro; a segunda, quando se nega direitos consagrados de jus gentium, como o trânsito por uma via pública ou o intercâmbio internacional, e a terceira, quando a injustiça fere a reputação ou a honra (dano moral). Essas injúrias constituem causa de guerra se perpetuadas tanto contra o soberano, como o povo, ou, ainda, um terceiro aliado. Neste caso, este último, além do direito, deve manifestar a vontade de reagir por meio da guerra. Cabe ressaltar que a satisfação da injúria serve até o limite da indenização do dano, bem como da punição do culpado ${ }^{40}$. Em Suárez, a punição constitui uma das modalidades dêonticas da lei e, portanto, pode ser realizada, de modo justo, pelo Estado ofendido.

Uma vez que o trabalho versa sobre duas virtudes, pode haver uma situação bastante interessante em que a causa seja justa, mas, ainda assim, contrária à caridade. Suárez afirma que se deve considerar, quando se encontra em face de uma guerra, o dano do Estado contra o qual se faz a guerra, o dano do Estado que empreende a mesma, e um dano o qual pode vir a ocorrer contra toda a Igreja. Neste último caso, há uma evidente dissociação entre a caridade e a justiça. Ainda que um rei cristão possua um título justo, na persecução de seu direito, ele pode vir a enfraquecer outro soberano cristão que esteja a segurar o avanço dos inimigos da fé. Aqui, o papa pode valer-se de seu poder indireto de ingerência para impedir que a contenda se consume. Em relação ao primeiro tipo de dano, não há obrigação de restituir porque eles foram provocados em virtude da má vontade do Estado ofensor de fornecer uma satisfação. Mas se, após a vitória, o ofendido cobrar uma indenização de que não precisa, e a qual o agressor não pode satisfazer sem gravíssimos inconvenientes, ele peca contra a caridade. No segundo caso, se o soberano ofendido se lançar à guerra sem considerar os danos que pode vir a sofrer, ele atenta contra tanto a caridade, como a justiça que deve ao seu povo. Ele expõe o seu reino a uma destruição que não guarda proporção com os bens lesados ${ }^{41}$.

Trata-se de uma situação muito interessante, pois representa uma

39 Cf. DB. $4,1$.

40 Cf. DB. 4, 3-4

41 Cf. DB. $4,6$. 
verdadeira concessão que a doutrina da guerra justa faz ao realismo político. O soberano não deve, ainda que, em princípio, a justiça lhe assista, embarcar em aventuras temerárias que possam vir a colocar o seu reino em perigo. Suárez justifica a sua posição pelo fato de que o príncipe deve zelar pelo bem comum e, neste caso, o remédio poderia matar o enfermo. Ele ainda observa que essa condição só se aplica em guerras agressivas, porque, nas defensivas, não há alternativa senão o combate. Acrescenta que esse critério se refere mais a uma probabilidade do que à certeza da vitória. Esta, não raro, não se permite desvelar antes da contenda. Por vezes, sequer interessa ao bem comum esperar por um grau de certeza absoluta. Além disso, se a exigência fosse da certeza, nunca um soberano mais fraco poderia declarar guerra a outro mais forte ${ }^{42}$. Nas ações coletivas, não se lida com certezas, mas com probabilidades e esperanças.

A seguir, Suárez analisa se os príncipes cristãos possuem outro título justo de guerra além daqueles prescritos na lei natural. Trata-se de saber se o fato de se professar a fé verdadeira confere alguma regalia que os pagãos não dispõem, se a guerra é "mais justa" aos cristãos do que a outros povos. Em princípio, Suárez responde de forma negativa. Não aceitar a religião verdadeira não confere nenhum justo título para a guerra, pois a conversão pressupõe uma adesão interna e não se pode obtê-la por meio da força. Por conseguinte, a idolatria também não constitui causa legítima. "Deus não deu a todos os homens o poder de vingar as injúrias cometidas contra $\mathrm{Si}$, porque poderia fazê-lo facilmente se quiser" $"$.

No entanto, se um chefe de Estado obriga, pela força, os seus próprios súditos a praticarem a idolatria, haveria um título justo de intervenção por parte de outro príncipe cristão. Neste caso, a ofensa não atinge a Deus propriamente, mas aos inocentes que desejam professar a verdadeira fé. Neste momento, Suárez e todos los maestros espanhóis, cujo pensamento ele sintetiza, revelam o cerne da escola espanhola da paz. Esse título "não é exclusivo dos cristãos, mas é comum a todos os infiéis que prestam culto a um único Deus" ${ }^{4}$.

Eis aqui a maneira como o direito da guerra pode constituir um mínimo ético. É o monoteísmo, não mais a religião cristã, que representa a civilidade. É fácil perceber o por quê. O politeísmo que os europeus conheciam era o paganismo antigo e algumas escassas notícias das

42 Cf. DB. 4, 7-8.

43 "Deus enim non dedit omnibus hominibus potestatem vindicandi suas ipsius injurias, quia ipse facile id potest" (DB. 5, 1).

44 "(...) non proprius Christianorum est, sed communis cum iis infidelibus, qui unum tantum Deum colerent" (DB. 5, 3). 
religiões africanas. Em todas elas, encontrava-se presente a ideia de sacrifícios humanos e de canibalismo, o que já era considerado bárbaro. Ademais, tanto o islamismo como o judaísmo, as outras duas grandes religiões monoteístas, pregavam valores de amor mútuo e respeito ao próximo, com os quais os cristãos conseguiam identificar-se. Fora das religiões reveladas, a civilidade não era uma certeza.

A prova de que o argumento de Suárez se centra na civilização, não na religião, é o fato dele radicalizar o raciocínio. Príncipes cristãos, portanto, podem intervir em Estados não cristãos para defender aquele povo de seu soberano idólatra. Mas podem intervir também em Estados cristãos, se o príncipe se converteu ao paganismo e resolveu forçar a conversão do seu povo. E reis muçulmanos podem fazer o mesmo tanto com outros soberanos muçulmanos que tenham se desviado, como, até mesmo, com príncipes cristãos. Em nome do monoteísmo e da civilização, Suárez permite que soberanos não cristãos intervenham em Estados cristãos ${ }^{45}$.

Desde Vitória, os escolásticos sabiam que os índios possuíam títulos justos de propriedade e de domínio de suas terras. Suárez pondera a concepção aristotélica da escravidão natural, mas não aceita uma aplicação geral da tese, porque "existem muitos infiéis melhor dotados do que certos cristãos e mais dispostos para a vida política" ${ }^{\text {. }}$. Não se pode, portanto, privar os infiéis de suas posses, nem de seu governo de modo justo. Para que isso fosse possível, não bastaria que um determinado povo fosse menos inteligente. Faz-se necessário que ele se mostrasse tão atrasado que

vivessem mais como feras do que como homens (...), [um povo desprovido de qualquer esboço de organização política, cujos membros passeiam] inteiramente desnudos, que se alimentam de carne humana, etc. Se essa classe de homens existir, é possível sujeitálos por meio da guerra não para destruí-los, mas para organizá-los de modo humano e para que sejam governados com justiça. Mas este título raramente ou nunca deve ser admitido, exceto quando ocorre a morte de inocentes e outros crimes parecidos. Dessa forma, este título ajusta-se melhor à idéia de defesa do que a de guerra agressiva. ${ }^{47}$

45 Cf. DB. 5, 3.

46 “(...) multos esse infideles ingeniosiores fidelibus, et aptiores ad res políticas" (DB. 5, 5).

47 “(...) potius ferarum more quam hominum vivat, (...) nudi prorsus incedunt, carnibus vescuntur humanis, etc. Et si qui tales sunt, debellari poterunt, non ut interficiantur, sed ut humano modo instituantur, et juste regantur. Raro tamen aut nunquam admittendus est talis titulus, nisi ubi intercedunt occisiones hominum innocentum, et símiles injuriae: quare potius titulus hic revocatur ab bellum defensivum, quam aggressivum" (DB. 5, 5). 
De todo o modo, se existir semelhante título, ele se estende a todos os reis que desejam defender a civilização, não somente aos cristãos.

Há - sem dúvida - limites para essa tolerância religiosa. Se um Estado não cristão deseja se submeter à lei de Cristo, mas o governante impede, os soberanos cristãos poderiam defender os inocentes. Porém, se a civilização não se encontrar em perigo, o mesmo direito não se estende a outras religiões monoteístas. Se este mesmo Estado quiser receber a religião maometana e seu regente não permitir, e neste lugar não se pratica nenhuma barbárie como canibalismo ou sacrifícios humanos, não haveria direito por parte dos soberanos turcos de intervir ${ }^{48}$. A civilização identifica-se com o monoteísmo, mas só o cristianismo encerra a Verdade. E a Verdade pode ser defendida por aqueles que a conhecem e aqueles somente.

Outro obstáculo, no que se refere ao estudo das causas justas, que os doutrinadores da tradição do direito de guerra precisavam defrontarse corresponde ao da bilateralidade da justiça numa guerra. Se dois soberanos possuíssem direito a um mesmo bem, ambos apresentariam um título legítimo. Ocorre que um teólogo não poderia aceitar isso, pois implica que a vontade de Deus não seria unívoca, ou a Sua criação imperfeita. Os maestros espanhóis resolveram esse problema ao apelar para uma dimensão que Suárez haveria de descobrir nas suas Disputações Metafísicas: a subjetividade. A justiça, de um ponto de vista objetivo, permaneceria una, e apenas um lado possuiria, de fato, um título justo; todavia, se houvesse uma ignorância invencível, um erro escusável, então haveria, de maneira subjetiva, a bilateralidade da justiça.

Desse modo, haveria uma obrigação, por parte de cada lado, em evitar o erro ao máximo. Suárez aceita esse dever. Ele mostra que existem, em cada contendor, três classes de pessoas envolvidas numa guerra: o governante, os políticos e os chefes militares (os quais se encarregariam da estratégia), e os soldados. Parece lógico supor que essas pessoas se encontram em uma ordem decrescente de obrigação de diligência na investigação sobre a justiça da guerra. O soberano deve sempre agir com mais cuidado. O segundo escalão deve perscrutar com a mesma atenção se a sua opinião for solicitada; caso contrário, deverá agir como os soldados. E estes, em geral, devem obedecer aos comandos, salvo se a injustiça for manifesta ${ }^{49}$. O estrito cumprimento do dever legal constitui uma escusa importante, mas não os exime de toda obrigação moral. 
Entre todas essas pessoas, paira sobre o príncipe a responsabilidade maior. Suárez passa a ensinar algumas regras para evitar o erro. Se os dois lados possuem direito a uma mesma coisa, o soberano deve comportarse como um juiz e, assim, julgar a qual dos dois a probabilidade favorece. Mais uma vez, o autor compara a guerra a um procedimento judicial. Se a destruição da guerra equivale a uma sanção penal, este procedimento de investigação e atribuição do direito corresponde a um "ato de justiça distributiva pela qual deve ser preferida a parte mais digna"50. Se houver igual probabilidade ou uma incerteza muito grande, o bem deve permanecer com o possuidor, conforme as normas jurídicas vigentes à época. Se a dúvida precede a posse, o possuidor posterior deve dar ao outro lado a satisfação proporcional à dúvida. Apenas na hipótese de igual dúvida - e ninguém possuir a coisa -, Suárez aceita a bilateralidade da justiça. Trata-se de uma ignorância invencível. Ainda assim, os dois reis devem evitar a guerra, dividir a coisa ou buscar outro procedimento para a atribuição do bem, como o arbitral. Nesta situação, não há perigo de injustiça; portanto, a arbitragem apresenta-se como o melhor meio para a resolução do problema. Somente se uma das partes se recusar a qualquer uma dessas soluções, ocorrerá a guerra, e ela será justa (apenas subjetivamente) para ambos os $\operatorname{lados}^{51}$.

Em relação à última condição - o comportamento digno antes, durante e depois das hostilidades -, Suárez também distingue obrigações diferenciadas para cada classe de pessoas. Aqui, o jurista de Coimbra arrola várias hipóteses de jus in bello; são diversas prescrições bastante pontuais e de difícil agrupamento. Ele se propõe a responder as seguintes perguntas: o que se permite fazer aos inimigos?; como deve se portar o rei com os seus soldados e vice-versa?; como cada classe de pessoa deve tratar aqueles que os abrigam durante as expedições militares?. O autor encontra respostas bastante humanas, em face do padrão de violência da época. Descobre que a reparação deve ser aceita mesmo com a guerra já em curso, desde que ela ainda não pendesse, de forma inexorável, para um dos lados. E esta satisfação inclui a restituição da coisa, a indenização dos danos e o castigo dos culpados, mas deve agir-se com parcimônia para não impedir a paz futura. Distingue entre combatentes (todos os que efetivamente tomam parte das hostilidades e os que poderiam tomar) e não combatentes (mulheres, crianças e velhos). Mostra que se deve proteger a vida dos inocentes. Demonstra ainda que, depois da guerra, quando o vencedor for cobrar a indenização e punir os culpados, pode dispor dos bens dos inocentes, mas nunca de suas vidas. Recomenda, todavia, sempre a moderação ${ }^{52}$.

50 “(...) ille est actus justitiaedistributivae, in qua dignior est praeferendus" (DB. 6, 2).

51 Cf. DB. 6, 2-5.

52 Cf. DB. 7. in totum. 
A seguir, Suárez passa a abordar as chamadas "guerras mistas" e as "guerras privadas", nas quais uma ou ambas as partes não são autoridades públicas e, assim, legítimas. A primeira delas, a sedição, nem sempre se apresenta injusta. Quando o príncipe passa a governar não para o bem comum, mas para o seu bem pessoal, ele se transforma num tirano, e a guerra do povo contra o seu governante torna-se lícita ${ }^{53}$. Por sua vez, a guerra privada por excelência é o duelo, que equivale à luta de particulares que ocorre sobre certas condições públicas. Mas há outra que se dá às escondidas: a rixa. Em ambas, matar alguém sob autoridade privada revela-se injusto ${ }^{54}$.

\section{Conclusões}

O direito de guerra escolástico não refletia as normas da guerra vigentes à época. Los maestros espanhóis escolheram algumas regras que constituíam uma prática corrente, mas prescreveram outras que, embora nem sempre decorressem do direito natural, representavam preceitos que humanizavam a guerra e dificultavam a sua ocorrência. Não pretendiam acabar com a mesma porque, na ausência de um juiz universal, ela cumpre uma função importante de justiça distributiva. Porém, procuravam fazer da paz o objetivo principal da guerra. Ela não é um simples fato, mas a realização cruenta do direito a serviço da paz internacional.

Ainda assim, a guerra justa escolástica representa mais do que um direito. Se fosse somente um jus, essa construção teórica se circunscreveria a um determinado continente e tempo. A justiça, por si mesma, não bastaria para fundamentar o direito da guerra. Como esse ramo contém preceitos positivos, não se poderia universalizar a justiça. Dessa forma, o Doutor Exímio recorre a outra virtude que, embora possua origens religiosas, é comum a todo povo que atinge um determinado grau de progresso espiritual: a Caridade. Isso permitiu que o direito da guerra não se tornasse um direito particular.

Embora o cristianismo não pudesse mais ser universalizado por causa da Reforma, visto vez que o direito da guerra extrapola o jus e ingressa no domínio da caridade, o relativismo dá lugar a uma ordem objetiva de valores. Por isso, essa ordem pode ser prevista e descrita de antemão, ainda que o estudo resulte numa obra casuísta. As regras singulares desse tratado, embora de difícil reunião, todas possuem um fundamento não propriamente religioso, mas de civilidade. 
Por isso, Francisco Suárez pode pensar a guerra sempre em função da paz. O direito de guerra compreende normas que visam salvaguardar, entre os povos, a convivência pacífica e harmoniosa posterior. $\mathrm{Na}$ disputação número onze do Tratado da Caridade, o autor distingue dois aspectos da paz: um positivo, a harmonia de vontades e unidade de critérios, de fins e de palavras, e outro negativo, a renúncia a todos os atos que possam dissolver essa harmonia. Luciano Pereña traduz esses dois elementos como a justiça - a qual dá ordem e sentido para a atividade dos homens e das gentes - e o princípio da humanidade que modera aquela ao promover laços mais profundos entre os homens, relações de amor e de amizade ${ }^{55}$. Apenas a justiça e a humanidade juntas, o Direito e a Caridade, podem prescrever regras universais de civilidade. $\mathrm{Na}$ ausência de uma religião válida para todos os povos, é a civilização que fundamenta o direito internacional.

\section{Referências bibliográficas}

AGOSTINHO. (1958) Obras de San Agustin: La Ciudad de Dios. Trad. José Moran. Edição bilíngüe. Madrid: BAC.

. (1993) Obras de San Agustin: Escritos antimaniqueos. Contra Fausto. Trad. Pío de Luis. Edição bilíngüe. t. XXXI. Madrid: BAC.

AQUINO Santo Tomás de. (1947) Suma Teologica. Texto latino de la edición crítica Leonina. Trad. Francisco Barbado Viejo, O.P. 2. ed. Madrid: Biblioteca de Autores Cristianos.

BORGES DE MACEDO Paulo Emílio (2009) O nascimento do direito internacional. São Leopoldo: UNISINOS.

CICERÓN (1954) De la République - Des Lois. Trad. Charles Appuhn. Edição bilíngüe. Paris: Garnier Frères.

FUSINATO G. (1885) "Le droit international de la République Romaine" Revue de droit international et de législation comparée, pp. 270-310.

GENTILI Alberico. De Iure Belli Libri Tres. Hannover: G. Antonius, 1612. Disponível na internet em $<$ http://gallica.bnf.fr $>$. Acesso em julho, 2012.

55 Cf. PEREÑA, Luciano. Estudio Preliminar. In: SUÁREZ, Francisco. Guerra Intervención Paz Int 
O direito da guerra em Francisco Suárez... Paulo Emílio Vauthier Borges de Macedo

GRATIANUS. Decretorum Codex. Venetiis: Nicolai Jenson Sallici, 1477. Reprodução do microfilme. Disponível em <http://gallica.bnf.fr/>. Acesso em julho, 2012.

HAGGENMACHER Peter (1983) Grotius et la doctrine de la guerre juste. Genève, Paris: Heige, Presses Universitaires de France.

HOWARD Michael, ANDREOPOULOS George, SHULMAN Mark (org.) (1994), The Laws of War: constraints on warfare in the Western World. New Haven, London: Yale University Press.

ISIDORUS HISPALENSIS EPISCOPUS (1911) Etymologiarum sive Originum. Libri XX. ed. W. M. Lindsay. Oxford: Clarendon Press.

MESNARD Pierre (1977) L'Essor de la Philosophie Politique au XVIe Siècle. 3. ed. Paris: J. Vrin.

NYS Ernest (1894) Les Origines du Droit International. Bruxelles, Paris: Alfred Castaigne, Thorin et fils.

ROMMEN Heinrich (1998) The Natural Law. Tradução para o inglês de Thomas Hanley. Indianápolis: Liberty Fund.

SCOTT J. B. (1934) The Catholic Conception of International Law. Washington D.C.: Georgetown University Press.

SUÁREZ R. P. Francisci (1956) Guerra Intervención Paz Internacional. Tradução para o castelhano de Luciano Pereña. Madrid: Espasa-Calpe.

. (1858) Opera Omnia. Editio Nova. Parisiis: Ludovicum Vivès.

.(1621) Opus de Triplici Virtute Theologica, Fide, Spe et Charitate. In Tres Tratactus pro Ipsarum Virtutum. Conimbricae: Nicolai Carvalho Universitatis Typograhi, Tratado da Caridade, Disputatio XIII, De Bello.

TRUYOL y SERRA Antonio (1944) El Derecho y el Estado em San Agustin. Madrid: Revista de Derecho Privado.

VANDERPOL Alfred (1919) La Doctrine Scolastique du Droit de Guerre. Paris: Pédone.

VITORIA Francisco de (1960) Obras de Francisco de Vitória. Relecciones Teologicas. Editadas por Teofilo Urdanoz. Madrid: Biblioteca de Autores Cristianos. 